\title{
ARV OCH NATION: NATIONALROMANTIK I ETT NATURHISTORISKT MUSEUM
}

\section{Eric Hedquist}

När det naturhistoriska museet i Slottsskogen i Göteborg öppnades den 8 juli 1923, möttes besökarna av en nyuppförd byggnad i rött tegel med flera flyglar och torn. ${ }^{1}$ Den skådesamling som därefter erbjöds deras nyfikna ögon kom att länge bli bestående oförändrad. Utställningar verkar genom estetiska medel, belyser en verklighet, förmedlar en mening eller en idé. Kan denna utställning frän 1920-talet tolkas mot bakgrund av det andliga och politiska klimat som rädde vid tiden kring museets uppförande? Följande uppsats avser att söka belysa detta museologiska spörsmål. ${ }^{2}$

\section{EN MUSEIBYGGNAD}

Museibyggnaden uppvisade en arkitektonisk stil som tillhörde tiden före första världskriget. Fullständiga ritningar till byggnaden hade gjorts av arkitekten Ernst Torulf redan 1915. ${ }^{3}$ Kriget och de följande krisåren hade fördröjt bygget med flera år. ${ }^{4}$

Säteritaket över den största av byggnadskropparna erinrar om byggnadskonsten under den karolinska tiden, svensk stormaktstid. Det reser sig över den del av byggnaden som rymde museets stora systematiska utställning. Huvudingången består av ett valv med kraftfullt huggen ornamentik i gråsten, på avstånd lik de portaler som prydde 1600-talsfasader i Stockholms Gamla stan. Strävpelarna på den östra flygeln har sannolikt inte någon kon- struktiv utan främst en ornamental funktion. (Figur 1) Materialen var omsorgsfullt valda. Sålunda kom teglet från Slottsmöllan i Halmstad, ett tegelbruk vars produkter åtnjöt stort anseende. ${ }^{5}$ Man föreställde sig vid denna tid att oputsade tegelfasader var speciellt svenska. ${ }^{6}$

De element jag hittills pekat på har kunnat förknippas med en allmän föreställning om svensk arkitektur under äldre tid och därmed om svenska ideal. Kupoltaket (Fig. 1, t.v.) över den byggnad som inrymde museets dioramor, har däremot en utformning med speciell syftning; det efterliknar den välkända kupol som täcker anatomisalen på Gustavianum, den gamla universitetsbyggnaden i Uppsala. Anatomisalen, Theatrum anatomicum, är ett minnesmärke över svensk naturvetenskap och biologisk museiverksamhet. ${ }^{7}$ Den byggdes och in- 
Eric Hedquist

96

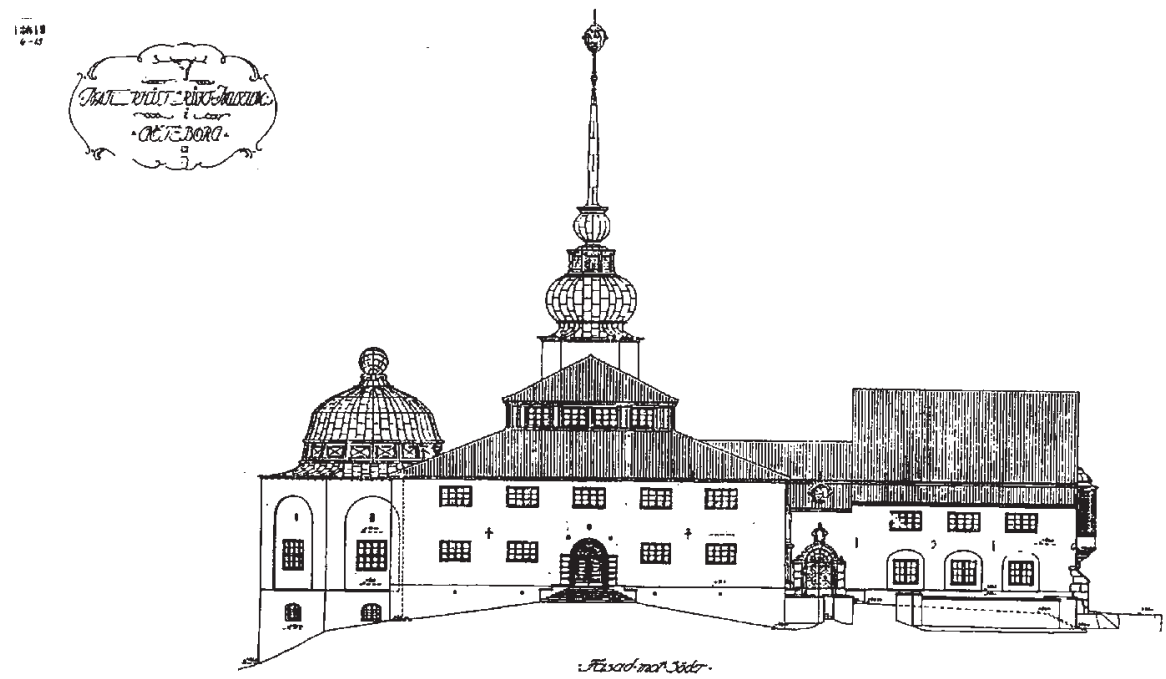

Figur 1. Göteborgs naturhistoriska museum från söder. Ritning av Ernst Torulf den 2 juni 1916.

rättades av naturforskaren och lymfkärlsystemets upptäckare Olof Rudbeck den äldre. Här förvarades sedan Rudbecks tid universitetets anatomiska preparat och skelett. ${ }^{8}$ Till universitetet i Uppsala kom 1728 den unge Carl von Linné som student efter det år han tillbragt i Lund. ${ }^{9}$ Gustavianums torn med dess karakteristiska yttre kupol och globformade solur har bevarats till våra dagar. Silhuetten av kupolen ovan dioramabyggnaden vid museet i Göteborg var lätt igenkännlig för besökare med akademisk bakgrund och låg nära att förknippa med Rudbeck och dennes framgång som naturforskare. ${ }^{10}$ Tanken har därvid kunnat löpa vidare till Carl von Linné som den mest berömde i raden av uppsaliensiska och svenska naturforskare.

Museets inre omfattades av samma av stormaktstiden inspirerade formspråk som exteriören. Också i valet av material till montrerna anas en symbolisk innebörd; enkelt utförda i fur erinrar de om de skåp som rymde
Carl von Linnés dyrbara naturaliesamlingar. ${ }^{11}$ Även $\mathrm{i}$ inredningen i övrigt finns element som erinrar om äldre arkitektur, särskilt markant i takmålningarna med förebild i barockens inredningar i slott och kyrkor. I vestibulen möttes besökarna av bilden av Adam i Edens lustgård (Bild 1).

\section{MusEOgRAFISKT MINNESMÄRKE}

Museets skådesamling är intressant, eftersom det framför allt är denna som i mångas ögon är museets berättigande. Men det făr inte glömmas att museet bedrev en omfattande insamling med vetenskapliga syften och successivt engagerade sig även i naturvården. ${ }^{12}$

Utställningen inrymdes i bottenvåningens gallerier i det så kallade museihuset och fortsatte på övre planets gallerier och i en stor sal med överljus. Detta plan stod via en passage $i$ förbindelse med dioramatornet och valsalen. ${ }^{13}$ Hela den zoologiska utställningens monterin- 


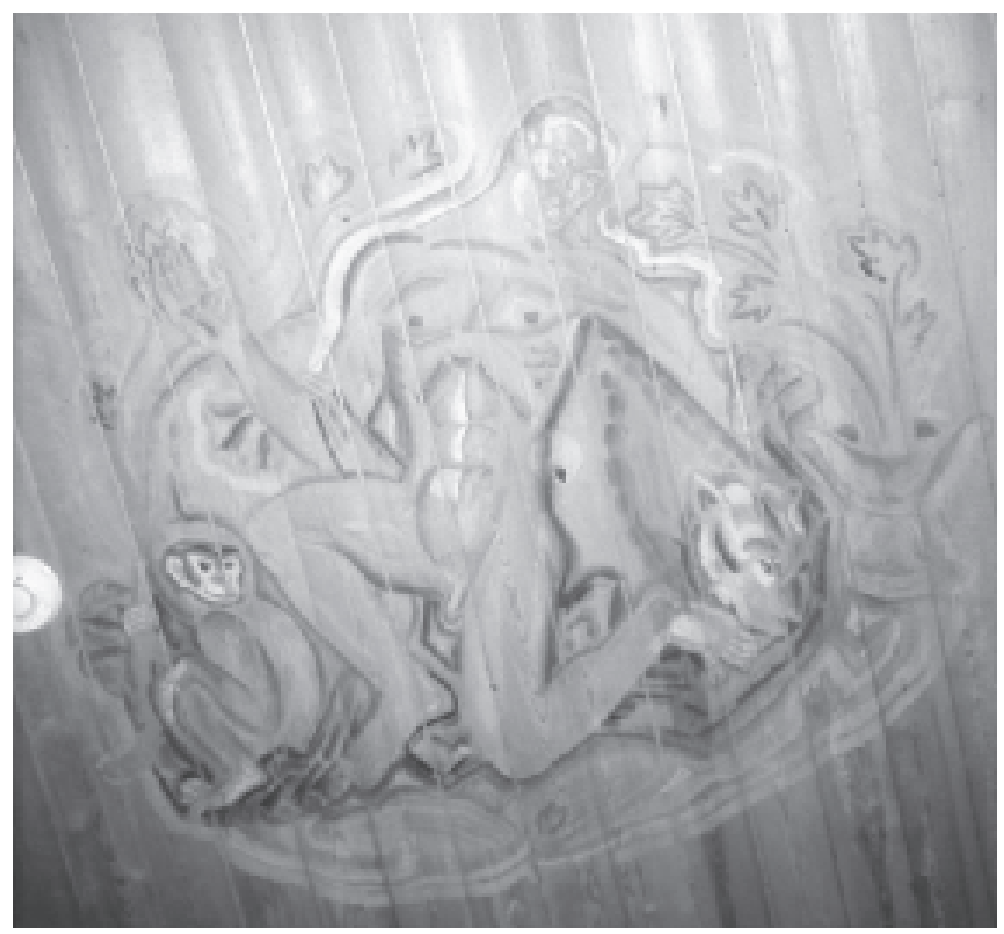

Bild 1. Adam bland djuren i Edens lustgård. Göteborgs naturhistoriska museum.

redning är orörd, även om innehållet i de flesta fall glesats ut och kompletterats med ny text och nytt bildmaterial. ${ }^{14}$ Utställningen från 1923 i Göteborgs naturhistoriska museum är ingenting mindre än ett museografiskt minnesmärke.

\section{SySTEMET FÖR DJURRIKET}

Vid invigningen av museet deklarerade museichefen, Leonard Jägerskiöld, i det tal han höll, att museet "måste i första hand tänka på att vara undervisningen och folkbildningsarbetet till tjänst. Det måste ge en redig systematisk framställning av djurriket och bringa blivan- de lärare en fast vägledning."15 I gallerierna visades olika djurgrupper, på nedre planet encelliga djur, svampdjur, nässeldjur, maskar, leddjur, blötdjur, tagghudingar, fiskar, groddjur och kräldjur. På övre planet visades i gallerierna utländska och svenska fåglar, i den stora salen mellan gallerierna däggdjuren. ${ }^{16}$ Valarna visades dock för sig, i den stora valsalen. De olika grupperna skildes i gallerierna av tvärgående väggar. Stora, alltjämt bevarade skyltar av svart lackerad metall med namnen i guld på de djurgrupper som visades var uppsatta i öppningarna mellan de olika rummen i gallerierna. ${ }^{17}$

Vilket är det system som tillämpades? - är 


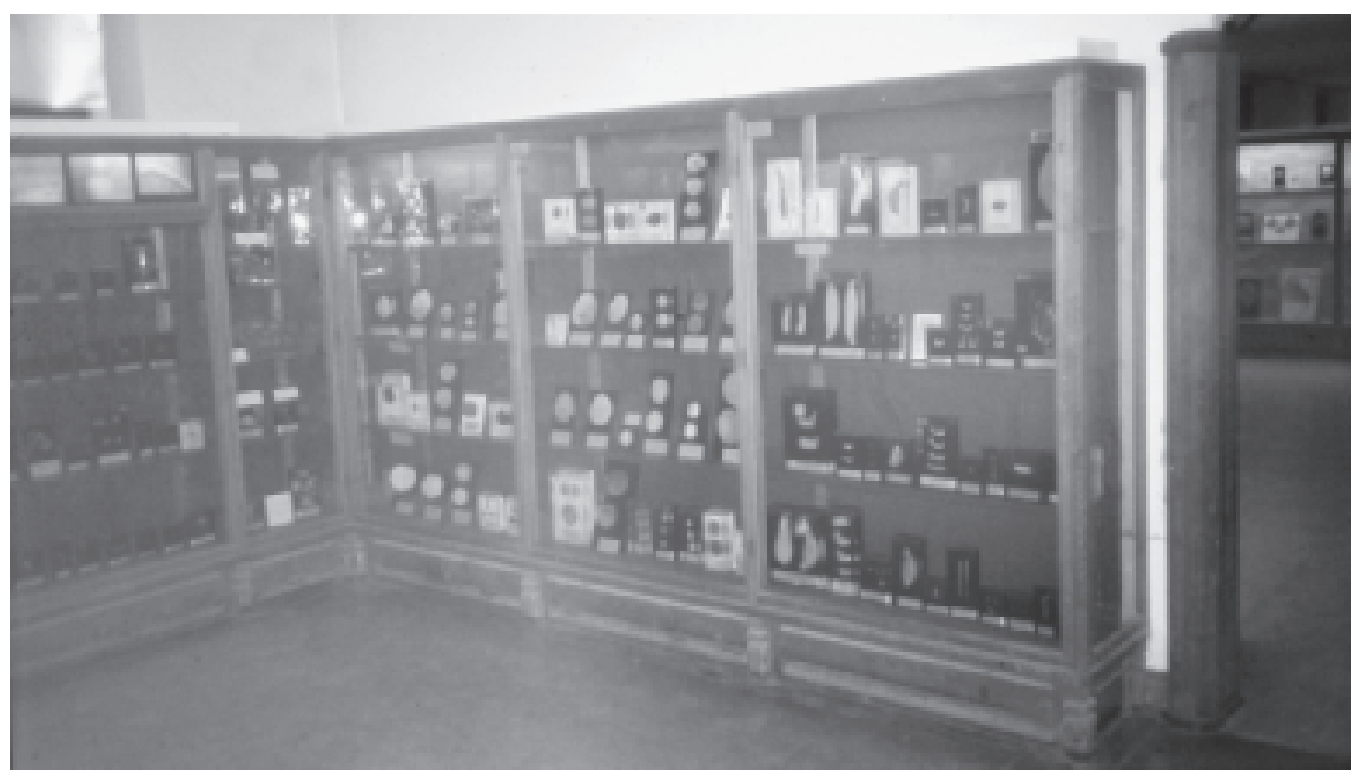

Bild 2. Montrer innehållande tagghudingar och manteldjur. Göteborgs naturhistoriska museum.

den fråga som inställer sig. Museets informationsskrift från 1924 ger en redogörelse för skådesamlingens innehåll men lämnar bara knapphändiga besked om systemet. Det omnämns kort och gott som "det vetenskapliga zoologiska systemet"18 Det låter sig emellertid jämföras med det system, som återgavs i andra upplagan av Nordisk familjebok, där zoologen och professorn vid Stockholms högskola Wilhelm Leche författat artikeln om djurriket. Det var ett system som delade djuren i två huvudgrupper:

Protozoa (encelliga djur)

Metazoa, (flercelliga djur)

Metazoa, de flercelliga djuren, var i sin tur delade i sex grupper:

$\begin{array}{ll}\text { Kavitetsdjur } & \text { Blötdjur } \\ \text { Tagghudingar } & \text { Leddjur } \\ \text { Maskar } & \text { Ryggradsdjur. }{ }^{19}\end{array}$

Det är i sina huvuddrag samma system som tillämpades i museets skådesamling, men ryggradsdjuren hade där inte angivits som en egen grupp utan ersatts av de olika klasserna fiskar, groddjur och kräldjur samt däggdjur i enlighet med Linnés system. ${ }^{20}$

Det system Leche återgav i Nordisk familjebok användes i den tyske zoologen Carl Gegenbaurs forskning under 1800-talets andra hälft. Gegenbaur syftade till att framställa ett stamträd utvisande djurgruppernas utveckling. Det var ett system som tillämpades av forskare som omfattade descendensteorin, det vill säga teorin om släktskap mellan alla djur; det har skett en utveckling från i allmänhet enklare till mer komplexa arter. ${ }^{21}$ Djuren i museet var alltså i huvudsak ordnade $\mathrm{i}$ grupper som vid tiden för museets planering var förenliga med evolutionsteorin, men systemet var som 


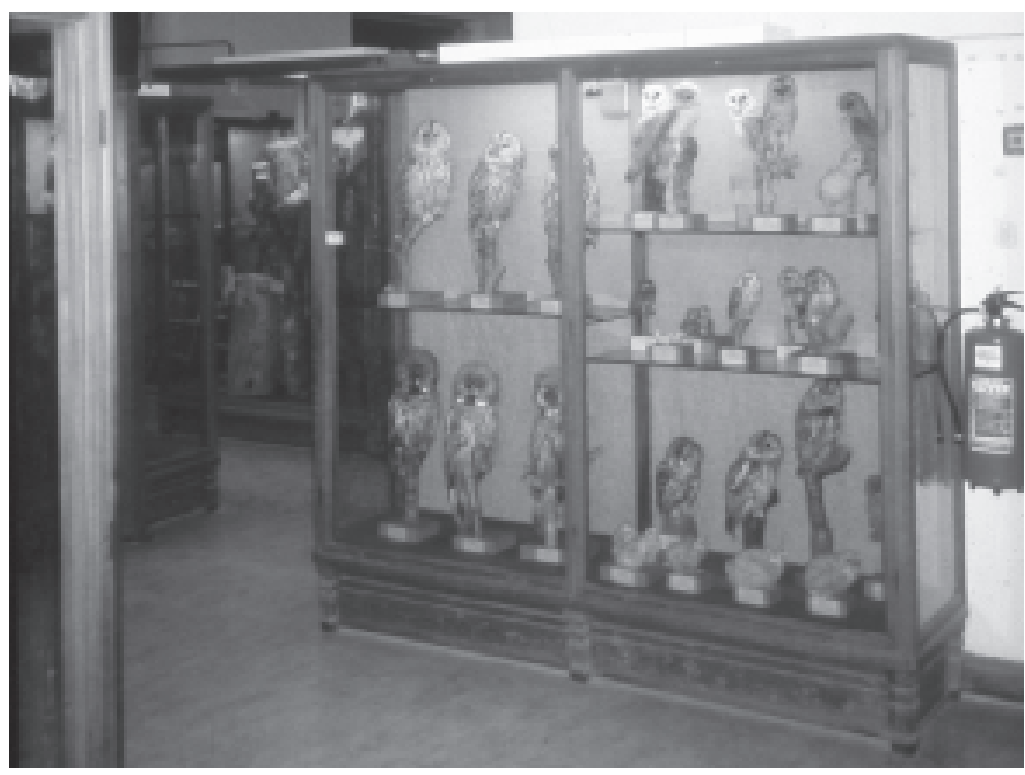

Bild 3. Monter med ugglor. Göteborgs naturhistoriska museum.

vi sett inte tydligt avläsbart. Genom att gruppen ryggradsdjur inte stod angiven utan var ersatt med klasser enligt Linné, kunde systemet förväxlas med ett system som byggde på andra grunder än utvecklingsläran. En av Linnés klasser, maskarna, förekommer dessutom som en av grupperna både i Gegenbaurs och museets system.

Saken gjordes inte tydligare av att museets informationsskrift benämnde alla museets huvudgrupper provinser, antingen de var stammar i Gegenbaurs system eller utgjorde klasser i Linnés system. Dessutom kom enligt museets redovisning av systemet även encelliga djur att betecknas som en provins, trots att de har en högre taxonomisk rang. ${ }^{22}$

Linné präglade emellertid skådesamlingen inte bara med indelningen i klasser enligt hans system utan framför allt i att den kunskap som förmedlades främst var artkunskapen. Utställningen innehöll knappast någon text. Utöver de skyltar jag nämnde var det i huvudsak endast lakoniskt formulerade etiketter som förekom. ${ }^{23}$ En etikett fanns på varje föremål, den rymde artens namn, på latin och svenska. Dessutom fanns uppgifter med hänvisning till museets katalog samt ofta namnet på den person som svarat för föremålets förvärv. ${ }^{24} \mathrm{Ge}$ nom det latinska namnet fick besökaren inte endast kunskap om artens namn utan även upplysning om vilket släkte det utställda djuret tillhörde.

Museets montrer var fyllda av radvis ordnade djur, släkte efter släkte (Bild 2). Besökaren blev bekant med de skilda arterna, som var utställda så att de med största möjliga tydlighet uppvisade sina yttre egenskaper, de flesta från $\operatorname{sidan}^{25}$ (Bild 3). Betoningen av artkun- 
Eric Hedquist

100

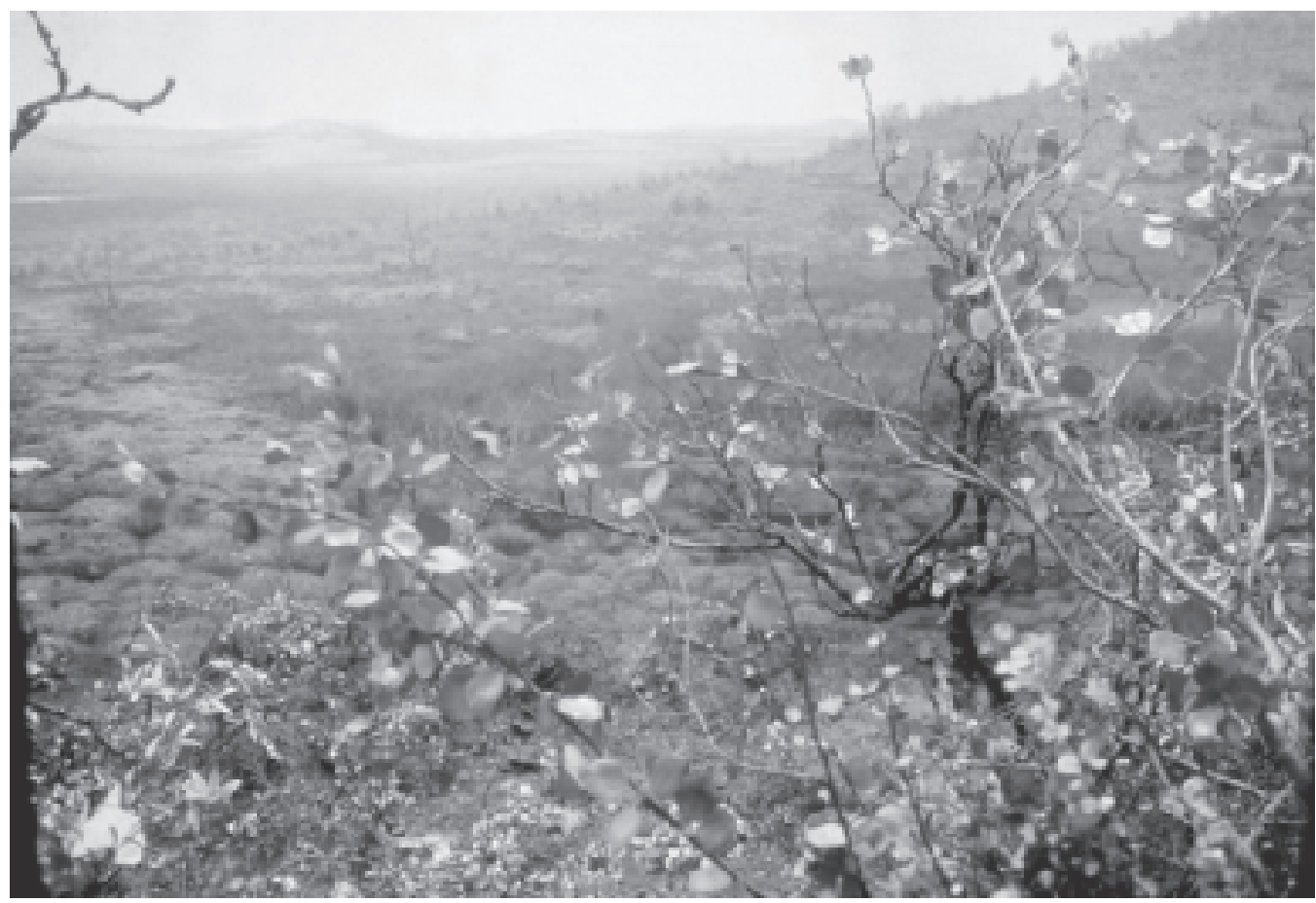

Bild 4. Tjiska söder om Kiruna. Diorama i Göteborgs naturhistoriska museum. Foto: Eric Jeansson.

skapen är ett utryck för den moral som är ett arv från Linné, i Systema naturae uttryckt i orden "Nomina enim si pereunt, perit \& cognitio rerum"(Ty om namnen gå förlorade, så går även kunskapen om de faktiska förhållandena förlorad). ${ }^{26}$

Utställningen var tillkommen i en tid då majoriteten av biologer var överens om att djurvärlden var resultatet av en utveckling. Kunde även gemene man här finna någon hänvisning till utvecklingsläran? I skådesamlingen fanns inte något kronologiskt perspektiv, här gavs ingen anvisning om den ordning i tiden enligt vilken de olika arterna tillkommit. Ingen stamtavla förklarade de olika grupper- nas förhållande till varandra. I stället fanns i taket innanför entrén till museet en målning som föreställde Adam bland djuren i Edens lustgård. Så här lyder i 1917 års kyrkobibel texten om Adam som namngivaren:

Och Herren Gud danade av jord alla himlens fåglar och förde dem fram till mannen för att se hur denne skulle kalla dem; ty så som mannen kallade var levande varelse, så skulle den heta. Och mannen gav namn åt alla boskapsdjur, åt fåglarna under himlen och åt alla markens djur. ${ }^{27}$

Utställningen kunde inte betraktas som en omedelbar spegling av evolutionen. 


\section{DiORAMOR}

Med dioramor avses med uppslagsbokens ord "illusionistiska helhetsbilder där verkliga föremål med hjälp av dekorationer visas i sitt rätta sammanhang. Tekniken är vanlig på museer för att åskådliggöra till exempel ett landskap.”28 I museet finns alltjämt i ursprungligt skick bevarade de fem dioramor som installerades $\mathrm{i}$ museet från början. Det är bilder från "i zoologiskt hänseende särskilt intressanta platser." ${ }^{29}$ De av intendenten vid Malmö museum Carl Olof Gylling konstfullt skapade scenerierna var hämtade från bestämda terrängavsnitt, fjälllandskapet i Kiruna (Bild 4), urskogen i de jämtländska fjällen, Stora Karlsö, Hornborgasjön och Måkläppen, ett strandrev i havet utanför Skanör. Alla dioramorna visade ett av människan orört landskapsavsnitt. Vyn över Hornborgasjön återger terrängen som den såg ut 1920, omedelbart före den sista dräneringen i det fruktlösa försöket att förvandla sjön till åkermark. ${ }^{30}$ Dioramorna gav en bild av det ömtåliga sambandet mellan växt- och djurvärld och mellan de olika arterna sinsemellan.

\section{Motiv}

För att tolka utställningen låt oss till en början se vilka uttalade motiv som fanns bakom museets och utställningens tillkomst. År 1903 publicerades i Ord och Bild en artikel om moderna zoologiska museer. ${ }^{31}$ Den var skriven av Leonard Jägerskiöld, en zoologidocent i Uppsala. ${ }^{32}$ Han var vid detta tillfälle en bland de sökande till tjänsten som chef för den naturhistoriska avdelningen vid Göteborgs museum och såg själv artikeln som en programskrift ägnad att förklara hur han uppfattade ett zoologiskt museums uppgift. ${ }^{33}$ I denna i det aktuella perspektivet viktiga skrift förklarade Jä- gerskiöld, att ett modernt zoologiskt museum i naturen. Han erinrade om att naturvetenskapen lämnat det stadium, då den främst var beskrivande. $\mathrm{Nu}$ gällde vetenskapen förklaringarna och orsakssammanhangen. De moderna zoologiska museerna hade också att "följa vetenskapens egen nyare utveckling tätt i spåren." ${ }^{34}$ Jägerskiöld fick inte tjänsten i Göteborg. Det blev emellertid hans tur när tjänsten blev ledig på nytt, bara ett år senare. ${ }^{35}$

Leonard Jägerskiöld fick uppgiften att som chef leda bygget av det nya naturhistoriska museet. Avsikten var enligt Göteborgs stadsfullmäktiges beslut att skapa ökade utrymmen åt de stora naturhistoriska samlingarna. Det var nödvändigt att råda bot på trångboddheten i Göteborgs museum. ${ }^{36}$ Redan 1911 hade museistyrelsen klargjort att den naturhistoriska avdelningen behövde skapa en mer ändamålsenlig skådesamling, bland annat för visning av dioramor. ${ }^{37}$ Man ville modernisera stadens museiväsen, det betraktades som primitivt att, som man hittills gjort, sammanföra konstverk och kulturhistoriska samlingar med naturhistoriska samlingar. ${ }^{38}$ Också en annan aspekt anlades, man talade om en "social museisynpunkt". Slottsskogen beskrevs som en folkpark. De naturhistoriska samlingarna skulle i denna omgivning vinna ökad betydelse "från folkuppfostringssynpunkt". ${ }^{39}$ När denna synpunkt i stadsfullmäktiges debatt i museisaken sattes i fråga av en av fullmäktigeledamöterna, genmälde vice ordföranden att museerna i högsta grad var en "kulturanstalt för de bredare folklagren" och tillade: "Jag tror att det är lyckligt att ha något som tävlar med kinematograferna." ${ }^{40}$

Det var emellertid endast litet som bestämdes i frågan om själva innehållet i museets utställning; av de officiella handlingarna fram- 
102 går blott att det gällde ett "modernt efter biologiska principer uppställt museum" ${ }^{41}$ Jägerskiöld hade dock under arbetet med planeringen av den nya byggnaden på tidigt stadium förklarat, att åskådaren i museet skulle kunna ”steg för steg följa det av vetenskapsmännen antagna systemet från lägre till högre djur hela skalan uppför". ${ }^{42}$ Några år efter museets öppnande liknades skådesamlingen vid "de levande varelsernas kedja”. ${ }^{43}$ Kedjans eller skalans idé saknade traditionellt varje samband med tanken på en utveckling. ${ }^{44}$ Den satte en tydlig prägel på Linnés åskådning. I Systema naturae ville han framställa allt $i$ "en redig kedja”. Ingen länk fick saknas. ${ }^{45}$ Ett viktigt drag i hans uppfattning uttrycktes i satsen "naturen fortskrider gradvis (per gradus), aldrig genom språng" ${ }^{46}$

\section{Evolutionen}

I utställningen kunde besökarna studera djuren från enklare till mer komplicerade arter, i full överensstämmelse med målsättningen. Det är visserligen möjligt, men långt ifrån nödvändigt, att betrakta detta som en återgivning av evolutionen. Även Linné, som inte byggde sitt vetande på teorin om en utveckling, betraktade organismerna i kategorierna enkla och sammansatta: "Skaparen har alltid fortskridit från det enkla till det komplicerade, och från det komplicerade till det mer komplicerade, och så vidare." ${ }^{7} 7$

Jägerskiölds ambition som han 1903 uttryckte den i Ord och Bild var rent vetenskaplig. Här yttrades inte något på metafysiskt plan, varken om en gudomlig skapelse eller förnekande av ett sådant underverk. På det vetenskapliga planet är det också - om än med viss möda - möjligt att finna, hur han som chef för det nya museet i Göteborg förverkligade vissa delar av sitt program. Vi har redan kunnat konstatera att han tillämpade en samtida systematik förenlig med evolutionsteorin. Det viktiga och avgörande elementet i denna teori enligt Darwin var emellertid det naturliga urvalet. Exempel på selektionen saknades inte $\mathrm{i}$ utställningen. Med hjälp av Darwins egen modellorganism, tamduvan, Columba livia, representerad av ett antal varieteter framställdes resultaten av människans urval. ${ }^{48}$ Det naturliga urvalet fanns också illustrerat, detta i avdelningen för insekterna, genom exempel på skyddande förklädnad, mimicry. ${ }^{49}$ Viktigt att notera är emellertid att dessa exempel på faktorer bakom evolutionen endast visades på ett minst sagt undanskymt sätt, synnerligen svåra att lägga märke till i den stora utställningen. I Jägerskiölds program 1903 ingick, att sådana naturlagar tvärtom skulle hållas fram, göras tydliga för utställningsbesökaren. Det fanns i utställningen en försiktighet, i uppenbar kontrast mot de avsikter Jägerskiöld annonserade, då han i Ord och Bild 1903 talade om vad som utmärker ett modernt zoologiskt museum.

Vi tvingas fundera över formuleringen "modernt efter biologiska principer uppställt museum”. Ostridigt är att det museum som invigdes i Slottsskogen i Göteborg sommaren 1923 var ett modernt museum, i byggnadstekniskt och museitekniskt avseende. Magasin och skådesamling var åtskilda, belysningsvillkoren var de bästa, kommunikationsvägarna genom byggnaden och utställningarna var de mest rationella. ${ }^{50}$ Så långt uppnåddes de uppställda målen till fullo. Men var det en "modern" utställning i beaktande av vilka "biologiska principer" som tillämpats? Visserligen följde utställningen i huvudsak ett vid denna tid erkänt system för klassifikationen av djurvärldens organismer. Detta motsvarar dock långtifrån de fordringar Jägerskiöld ställde på 
ett modernt zoologiskt museum, när han 1903 deklarerade att det hade att "följa vetenskapens egen nyare utveckling tätt i spåren."

\section{NATUREN SOM ARV}

Utställningen rymde emellertid mer än den systematiska utställningen. Här fanns också dioramorna med deras bilder av svensk natur. De har med sin starkt illusoriska verkan ägt betydande folklig attraktion. De hade vid tiden för sin tillkomst de största förutsättningar att väcka åskådarens intresse. Det var före färgfilmens tid - och långt före semesterlagens tillkomst. En arbetarfamilj i Göteborg hade vid tiden efter första världskriget ingen möjlighet att besöka dessa platser, men dioramorna förmedlar den upplevelse de bjöd. I den nationalromantiska ram, som bildades av museets arkitektur, var dioramorna ägnade att hos besökaren väcka känslan för naturen som ett värde att värna, naturen som ett arv. De hade en viktig egenskap i det att de var socialt neutrala, ty här visades naturen utan människans närvaro, före feodalism och kapitalism.

Karen Wonders har satt museets dioramor i samband med den traditionen från Linné. Hon har särskilt tänkt på den ådra som går tillbaka på hans naturskildring och vetenskapliga observation. Hon har också erinrat om den roll traditionen i Linnés efterföljd spelat som ideologiskt program för folklig undervisning. ${ }^{51} \mathrm{I}$ ett arbete av Björn Hettne, Sverker Sörlin och Uffe Östergård erinras om nationallandskapet, naturens monument och de geografiska kartornas betydelse för den nationella identiteten. De har bland annat intresserat sig för naturen som inslag i nationalismen och framhållit, hur naturen vid sekelskiftet 1900 gjordes till en upplevelse och en dimension av nationaliteten. Tidens konstnärer och författare skildrade skärgårdar och fjäll. En våg av in103 tresse för det egna landets natur gick fram genom hela Norden. Det unika och säregna hölls fram i varje lands natur. ${ }^{52}$ Gunnar Eriksson har i Kartläggarna (1978) förklarat den starka känslan för de nationella värdena som en överideologi, som vid tiden före första världskriget omfattade hela etablissemanget och kanske därutöver även nått in i folkets led. Nationalismen hade också att göra med en medvetenhet om landets resurser och potential. ${ }^{53}$

Vad besökaren i det naturhistoriska museets utställning erfor kan i betydande grad ha satt den patriotiska känslan i rörelse. Naturföremålens skönhet har i den nationalromantiska byggnaden med dess rika symbolspråk upplevts som bärare av värden tillhörande den svenska nationen, ett arv att vörda och värna.

\section{VÖRDNADEN FÖR NATUREN}

Hur skall bilden av Adam i Edens lustgård betraktas i sammanhanget? Den låter sig omöjligt förklaras som ren utsmyckning. Därtill var ämnet för allvarligt, för aktuellt. Förhållandet mellan tro och vetande under det sena 1800 talet och det tidiga 1900-talet i vårt land har undersökts av idéhistorikern Kjell Jonsson. Han har visat hur det under denna tid rådde ett växande intresse för den naturvetenskapliga världsbilden, men också hur naturvetenskapens expansion möttes av motstånd från kritiker som såg de etiska värdena hotade. De krävde av naturvetarna att de skulle inse sin begränsning. Många intellektuella kände behov av en religion, många var påverkade av monismen. Vetenskapsmannen The Svedberg erinrade sig tiden som kemiamanuens i Uppsala och hur han låtit sig påverkas av monismen, "en allmänt etisk panteism" ${ }^{54}$ Med Adamgestalten ställde museet det kristna budskapet i 
104 direkt motsats till Darwin och evolutionsteorin. Desto lättare var Adambilden att förena med Linnés åskådning, Linné som själv gav djuren namn och i naturen såg spåren av Skaparens hand. Agnostikern behövde därför inte nödvändigtvis ha känt motstånd mot Adambildens förekomst i museet. Utställningsbesökare utan kristen eller annan bestämd trosåskådning kan i panteistisk anda ha uppmärksammat Adambilden som en påminnelse om den aktning och vördnad människan allmänt kan erfara inför naturen.

En fråga är hur den bibliska och den naturvetenskapliga innebörden i utställningen kunde förenas $\mathrm{i}$ åskådarens sinne? Svaret hänger samman med frågan om hur utställningsbesökare skapar en mening av det sedda. Man måste föreställa sig att förloppet inte är diskursivt utan intuitivt. Det är inte bundet till en linjär ordning mellan ingående beståndsdelar. Skilda element i betraktarens minne förenas utan rangordning, polarisering eller val av alternativ. Betydelse skapas genom olika aspekter och möten mellan innebörder. Adambilden kunde observeras och bearbetas i betraktarens sinne utan att med nödvändighet sättas i motsats till naturvetenskapen. Den som reflekterade över Adamgestaltens närvaro i museet erinrade sig frågor av allmänt religiös eller filosofisk natur. Frågorna behövde inte för stunden besvaras i ord men kunde utöver sin intellektuella innebörd också erhålla en emotionell mening.

Besökaren försätts i en sinnesstämning som medförde vördnad för vad utställningen visade. En sådan hållning fick gensvar i de utställda djurens skönhet. ${ }^{55}$

\section{Makt och offentlighet}

Avsikterna bakom uppförandet av det nya naturhistoriska museet i Slottsskogen i Göteborg var vaga. Om min tolkning skall kunna försvaras, är jag skyldig att visa att den överensstämde med de tankar och föreställningar, som rådde i Göteborg under den aktuella perioden och kom till uttryck i en politik, i processen att utöva makt i det offentliga.

Vilka hinder har stått i vägen för Jägerskiöld, att i den utställning han framställde mer tydligt visa på evolutionen? Indirekt har han själv ställt frågan, men vi vet inte hur han besvarade den, eller om han alls besvarade den. I ett föredrag hållet någon gång efter 1907, med titeln "Biologins betydelse som bildningsämne” uppmanade Jägerskiöld skolan, att - åtminstone på högre stadium - undervisa om utvecklingsläran, "den ena organismens uppkomst ur den andra". "Varför ej?" frågade han, "Fruktas dogmatism?"56 Vi får lov att söka svaret i den intellektuella och andliga miljö som omgav Göteborgs museum och dess naturhistoriska avdelning.

\section{GÖTEBORGS HÖGSKOLA}

Viktigaste centrum i det intellektuella livet och därmed i museets omgivning var utan jämförelse Göteborgs högskola. Här utsågs Jägerskiöld till docent, inte i zoologi utan i ett ämne betecknat "djurgeografi och zoologi". Bakgrunden till denna unika ämnesbeteckning var att högskolan i Göteborg saknade en naturvetenskaplig avdelning. ${ }^{57}$

Dominerande gestalter vid högskolan var professorerna Ludwig Stavenow och Vitalis Norström. Stavenow, som var historiker, beklädde åren 1909-1914 posten som högskolans rektor. Han lämnade Göteborg 1914 för 
en professur i Uppsala, där han senare också skulle bli rektor..$^{58}$

Vitalis Norström var professor i filosofi från 1893 fram till sin död $1916 . .^{59}$ Han tillhörde kritikerna av en naturvetenskaplig världsåskådning och såg ett hot i dess determinism. Under 1880-talet hade han kritiserat Herbert Spencer för att denne återförde alla värdebegrepp till individens lycka eller njutning. Norström försvarade en hållning som innebar att oegennyttan måste grundas i idealism och rationalism. ${ }^{60}$ År 1910 gav Norström ut sitt populära arbete Masskultur, där han hyllade grekernas och romarnas idé om "det rätta".

Nutidsmänniskan, sade han, behövde en intelligensens religion som en "vetenskapens egentliga ljuskälla", ${ }^{61}$ I september 1907 förrättades invigningen av Göteborgs högskolas nya byggnad. Ett av talen vid denna högtid hölls av biskopen i Göteborgs stift, Edvard Rodhe. Från talarstolen uppmanade han högskolan, att bidra till att dämpa tidens religionsupplösande tendenser. Vid den följande middagen med närvaro av kronprinsen, den blivande konung Gustav V, framträdde dessutom ärkebiskopen Johan August Ekman med ett tal, där han erinrade om att den viktigaste av högskolans donatorer, en nyligen avliden industriledare och finansman, hade betraktat den evangeliska religionen som den säkraste grunden för folkets väl. Ludwig Stavenow citerade därefter i ett tal ett av ärkebiskopens yttranden: "All grundlig vetenskap leder till Gud". ${ }^{62}$ Stavenow var en av ledamöterna i Göteborgs museums styrelses byggnadsberedning och var i denna egenskap med och förverkligade det naturhistoriska museet. ${ }^{63} \mathrm{Han}$ har genom sin blotta närvaro i beredningsgruppen påmint om kyrkans och högskolans gemensamma vetenskapliga värderingar och intressen.
KYRKAN

Även om kyrkans betydelse minskade i samband med industrialiseringen och inflyttningen till städerna, var dess ställning en väsentligt annan och starkare än i vår tid.

Sedan 1888, anförda av stiftschefen Edvard Rodhe, var de schartauanska prästerna de dominerande inom Göteborgs stift. Schartauanismen varnade för världen och dess barn, tog avstånd från allt som hörde till den moderna kulturen, även nykterism. Socialdemokrati och liberalism betraktades som Antikrists förelöpare. ${ }^{64}$

En inflytelserik person som stod i kontakt med det naturhistoriska museet i Göteborg var kyrkoherden Ivar Daniel Wallerius. ${ }^{65}$ Bland gåvor till museet 1923 uppgavs i museets årsberättelse "En större samling subfossila mollusker m.m. insamlade av kyrkoherde fil. dr Ivar D. Wallerius från en skalbank vid Linneviken, Tjörn". ${ }^{66}$ Samma höst var Wallerius i museet i färd med att bestämma de ingående arterna i mollusksamlingen, som han senare publicerade i Geologiska föreningens förhandlingar. Även året därpå arbetade han i museet, nu bland annat med att av de fossila molluskerna ordna en "utmärkt vacker skådesamling". ${ }^{67}$ Wallerius hade en god position i förhållande till Göteborgs museum. Detta kom till tydligt uttryck genom att museistyrelsen i september 1925 tilldelade honom museets plakett i silver. ${ }^{68}$

Wallerius var från början geolog och hade disputerat $i$ ämnet 1895 . Han tillhörde liksom sin broder Adolf de ledande inom det schartauanska prästerskapet. ${ }^{69}$ Ivar Wallerius gav 1917 ut en bok med titeln Den moderna naturåskådningens kris. Här tog han avstånd från Darwin. I sin argumentering mot descendensteorin, arternas härstamning ur tidigare arter, kunde han hänvisa till egen forskning på den kambrosiluriska formationen i Västergötland. 
106 Han påvisade hur de trilobiter han studerat inte uppvisade några sådana övergångsformer, som skulle kunna tjäna som belägg för en utveckling enligt Darwins teori. ${ }^{70}$ Det är i vårt sammanhang värt att lägga särskilt märke till att han instämde med en tysk författare, Jacob von Uexküll, som betraktade organismerna som länkar i livets stora kedja. ${ }^{71}$ Boken avslutades med ett karakteristiskt Linnécitat: "Gud den evige, den allvetande, den allsmäktige har jag skymtat före mig och häpnat. Jag har upptäckt några hans spår i skapelsens verk - och i dessa alla, även de minsta, de som synes vara ingenting - vilken kraft, vilken vishet, vilken outgrundlig fulländning!"72

Wallerius bok har också en politisk dimension. Han varnade för den populära dagspressens materialism. Och bland folkets massor såg han en grogrund för denna åskådning: "Materialismen finner en utomordentligt fruktbar mark i storstädernas oerhört växande publik, som lärt bort att se några under och därför överallt tror sig se mekaniska lagar" ${ }^{73}$

Schartauanernas politiska ideal låg i stormaktstiden. Gustaf II Adolfs dödsdag den 6 november högtidlighölls med högstämda tal. Adolf Wallerius karakteriserade 1906 Gustav Adolf som "hela den germanska stammens upphöjdaste och ädlaste världshistoriska personlighet”. Fosterlandet var ett för schartauanismen upphöjt värde. ${ }^{74}$

\section{SOCIAL OCH POLITISK ORO}

1909 var året för en arbetsmarknadskonflikt som berörde mer än 300000 arbetare. Det rådde stora klassmotsättningar. ${ }^{75}$ Fem år senare följde nästa stora kris. Den 10 februari 1914 såg sig den liberale statsministern Karl Staaf och hans regering nödsakade att avgå till följd av konung Gustaf V:s utmaning av riks- dagen genom det berömda borggårdstalet inför bondetågets mer än 30000 deltagare. Beundraren av Karl XII Sven Hedin hade med skriften Ett varningsord hetsat upp stämningarna mot Ryssland och manat till ökade rustningsansträngningar. ${ }^{76}$

Det förvånar inte att en tid som denna leder till starka nationella stämningar bland dem som hyser oro för förändringens vind och farhågor för yttre hot. De nationella idealen har hållits som högst under tider av kris. ${ }^{77}$ Svensk nationalism var en "enandenationalism" i dess strävan att ena ett i skilda klasser splittrat samhälle. Det fanns i svensk nationalism en samlingstanke. ${ }^{78}$

\section{LINNÉARVET}

Tidsandan gick emot den moderna naturvetenskapen. I En blå bok (1907) skrev August Strindberg att "fader Darwins teorier" börjat skatta åt förgängelsen: "Men nu står Linné upp för att bli sin egen efterträdare." 79

Sten Lindroth har påmint om Linnés postuma öde. Med romantiken, ett stycke in på 1800-talet blev Linné en vägvisare in i mysterierna. Linne blev" ett med den svenska sommarens ljuvligheter. Romantikens Linnébild blev det svenska folkets egendom. Det följde ett kritiklöst förgudande. Med de stora Linnéfesterna 1878 och 1907 gav det oscariska Sverige sin officiella välsignelse åt kulten" ${ }^{80}$

Vördnaden för Linné måste betraktas som ett sant uttryck för nationalkänslan. Linné var en av dem som tidigast bidrog till en nationell natur. Efter honom konstitueras naturen i ett nationellt sammanhang. "Kärleken till naturen", skrev befolkningsstatistikern Gustav Sundbärg i sin berömda bilaga till Emigrationsutredningens betänkande, "är djupt rotad hos vårt folk.../Det är/ Linné, som bestämt rikt- 
ningen av vårt folks intresse för århundraden." ${ }^{81}$

Lisbet Koerner har påvisat hur minnet av Linné utnyttjades för att söka ena stridande grupper i samhälllet. Ludwig Stavenow erinrade i ett tal under Linnéjubileet vid Göteborgs universitet 1907 om den makt minnet av Linné ägde att tala till skilda samhällsgrupper. Det är betecknande att Stavenow emellertid inte blev oemotsagd. Den radikale biologen Bengt Lidforss genmälde, att landets alla fattiga förblev oberörda av jubileet och festtalen. ${ }^{82}$

\section{ArtKunskap \\ OCH IDEALISTISKT SKEN}

Museibyggnadens arkitektur erinrade om stormaktstiden, landets ärorika förflutna. Redan i Gustavianumkupolen ovan ett av taken på museibyggnaden i Slottsskogen påmindes Linnés beundrare om sin hjälte. I utställningen med dess betoning av artkunskapen och framställningen av djurriket i form av en kedja går en stark ådra av Linnés åskådning. Adam i Edens lustgård målad i taket omedelbart innanför huvudingången ger på en och samma gång en erinran om djurriket som Guds skapelse och om Adam som namngivare åt de levande varelserna och därmed som en i bildlig mening föregångare till Linné. Man påminner sig samtidigt Linné som en trogen kristen.

Den moderna biologin kom, i jämförelse med det nationalromantiska och av Linné präglade innehållet, endast till ett mycket vagt uttryck i museets utställning.

I de uttalade motiven bakom museet och utställningen finns inga hänvisningar vare sig till metafysiska perspektiv eller till äldre naturvetenskap. Men, i en tid av värn kring nationen, de kristna idealen och en kritisk hållning till naturvetenskap, gav i synnerhet Lin- néminnena naturvetenskapen ett idealistiskt 107 sken.

Tidens sociala och politiska oro möttes av en strävan, att med hänvisning till landets förflutna och dess natur väcka en enande känsla - en nationell gemenskap - på en gång för fosterlandets natur och dess historia. Bekännelsen till Linné och nationen kan förklaras som nödvändig för att i Göteborg vid tiden för första världskriget uppföra ett naturhistoriskt museum.

De många drag i naturhistoriska museet som var ägnade att hos besökaren väcka de patriotiska känslorna, får sin förklaring mot bakgrund av en allmän tidsanda och särskilt de uttryck den tog vid Göteborgs högskola och inom prästerskapet i Göteborgs stift. Biskopar och professorer utövade sin makt genom högstämd retorik och populära pamfletter. Deras mening och deras inflytande gjorde sig gällande utan att dokumenteras i de församlingar, där man fattade de formella besluten om det nya museet.

\section{Noter}

1. Naturhistoriskt museum i Göteborg. Göteborg den 2 juni 1916. Ernst Torulf. Göteborgs byggnadsnämnd. Oförtecknad. Göteborgs stadsarkiv.

2. Tema för höstens museidagar vid Umeå universitet den 6-7 november 2002 var kulturarv och politik. Denna text framlades som ett av de föredrag som hölls.

3. Leonard A. Jägerskiöld, Naturhistoriska museet i Slottsskogen: Dess historia, byggnad, inredning och invigning. Göteborg, 1924, 3.

4. Ibid. 4-8.

5. Ibid. 10; Eva Eriksson, Den moderna stadens fódelse: Svensk arkitektur 1890-1920. Stockholm, 1990, 299.

6. Andreas Lindblom, Sveriges konsthistoria: Frän 
108 forntid till nutid. Del 3, Stockholm, 1946, 929.

7. Karen Wonders, Illusion of Wilderness in Museums of Natural History. Uppsala, 1993, 78.

8. Yngve Löwegren, Naturaliekabinett i Sverige under 1700-talet: Ett bidrag till zoologiens historia. Lund, 1952, 162-167.

9. Vita Caroli Linnai: Carl von Linnés självbiografier. Utgivna av Elis Malmeström och Arvid Hj. Uggla, Stockholm, 1957, 49.

10. Den karakteristiska kupolen på Gustavianum med dess globformade solur har bevarats oförändrad till våra dagar. Dess inre restaurerades under åren efter 1946. Gunnar Nyström, Olaus Rudbeck's Anatomical Theatre in the "Gustavianum". Uppsala, 1964, 15.

11. Från ett besök i Linnean Society i London erinrade sig zoologen Leonard Jägerskiöld särskilt Linnés enkla montrer i fur. Leonard Jägersiöld, Upplevt och uppnått: Ur minne, brev och loggböcker. Helsingfors, 1943, 292. Ett av Linnés skåp finns även bevarat i Linnémuseet i Uppsala. Yngve Löwegren 235.

12. Göteborgs naturhistoriska museum 150 år: Arstryck 1983. Göteborg 1983, 33-34, 38-39, 41-46, 48-50, 69-70. Vid det högtidliga öppnandet av den 8 juli 1923 framfördes en välgångsönskan från Uppsala universitet, vari framhölls museets betydelse både för folkupplysningens främjande och som härd för vetenskaplig forskning. Jägerskiöld 1924, 23-24.

13. Jägerskiöld 1924, 11-13.

14. Mina iakttagelser är från åren före 1999.

15. Dagens Nyheter $9 / 7$ 1923, 1, 5.

16. Jägerskiöld 1924, 29-34.

17. Ibid.12.

18. Ibid.14.

19. Nordisk familjebok: Konversationslexikon och realencyklopedi Band VI, Stockholm, 1907, 559.

20. Både Linnés och Gegenbaurs system är i korthet presenterade i artikeln "Djur" i Nationalencyklopedin. Band 5, Höganäs 1991, 46.
21. Gegenbaur var inriktad på att klarlägga förbindelserna mellan de största taxonomiska grupperna inom varje rike. Läsningen av Darwin hade lett honom till föreställningen att han genom att bestämma de fylogenetiska banden skulle kunna härleda lagar om formerna. Lynn Nyhart, Biology Takes Form: Animal Morphology and the German Universities 1800-1900, Chicago \& London, 1995, 145.

22. Jägerskiöld 1924, 14, 29.

23. Ibid. 23.

24. Under tiden för mina observationer i museet, före 1999, fanns äldre bevarade etiketter i rik mängd. Men det är inte säkerställt att dessa etiketter var de ursprungliga från 1923.

25. Främsta källan till kunskapen om själva utseendet av den ursprungliga utställningen består av 15 foton av god kvalitet tagna av fotografen Anders Karrnell. Neg. 2735-2750. Glasplåtar och kopior. Göteborgs naturhistoriska museums arkiv.

26. Carl von Linné, Systema Naturae per Regna Tria Naturae (1735) tolfte upplagan, Holmiae, band I, 1766, 13.

27. Gamla och nya testamentet: De kanoniska böckerna. (1917) Stockholm, 1953, 11.

28. Nationalencyklopedin. Band 4, Höganäs, 1991, 6.

29. Jägerskiöld 1924, 12.

30. Jägerskiöld 1924, 12-13, 15-16.

31. Leonard A. Jägerskiöld, "Ett besök i Londons naturhistoriska museum." Ord och Bild, (1903) 271-286.

32. Svenskt biografiskt lexikon. Del 20, Stockholm, 1973-1975, 513.

33. I ett brev till en god vän i Göteborg berättade Jägersiöld att hans artikel i Ord och Bild var ett program och frågade om han borde sända särtryck till museistyrelsens ledamöter eller om de redan kunde antas ha sett den. Brev från Leonard Jägerskiöld till professorn i språkforskning vid Göteborgs högskola, Evald Lidén, den 28 maj 
1903. Göteborgs universitetsbibliotek.

34. Jägerskiöld, 1903, 272.

35. Svenskt biografiskt lexikon 513.

36. Göteborgs Stadsfullmäktiges Handlingar 1912. No 51,6

37. Jägerskiöld 1924, 3-4.

38. Göteborgs Stadsfullmäktiges Handlingar 1913. No 51,6 .

39. Ibid.7.

40. Göteborgs stadsfullmäktiges handlingar 1913. Yttranden vid Stadsfullmäktiges sammanträden. Häfte 5, 7.

41. Göteborgs Stadsfullmäktiges Handlingar 1914. No 51,7

42. Bilaga till Göteborgs Museums styrelses byggnadsberednings protokoll 24/1 1914. Protokoll med bilagor 1914 (AI:36) Göteborgs stadsarkiv.

43 . En bok om Göteborg. Red. Carl-Julius Anrick, Arthur Lindhagen och Mårten Stenberger, Stockholm, 1931, 112.

44. Arthur O. Lovejoy, The Great Chain of Being: A Study of the History of an Idea. Cambridge, Massachusets, 1936, 50-66.

45. Gunnar Broberg, Homo Sapiens L.: Studier i Carl von Linnés naturuppfattning och människolära. Stockholm, 1975, 78-79.

46. Citat efter Nils von Hofsten, "Linnés naturuppfattning", Svenska Linné-sällskapets årsskrift. Årgång XLI, 24.

47. Hofsten 20.

48. Göteborgs naturhistoriska museum, monter nr 282.

49. Jägerskiöld, 1924, 29.

50. Ibid. 11-12.

51. Wonders, 83-88.

52. Björn Hettne, Sverker Sörlin, Uffe Östergård, Den globala nationalismen: Nationalstatens historia och framtid. Stockholm, 1998, 328, 329.

53. Gunnar Eriksson, Kartläggarna: Naturvetenskapens tillväxt och tillämpningar i det industriella genombrottets Sverige 1870-1914. Umeå, 1978,
198, 201.

54. Kjell Jonsson, Vid vetandets gräns: Om skiljelinjen mellan naturvetenskap och metafysik i svensk kulturdebatt 1870-1920. Lund, 1987, 140, 143, 152-153.

55. Eric Hedqvist, "Skådesamling och åskådlighet", Kulturella perspektiv: svensk etnologisk tidskrift. 2001:4, 18-21.

56. Föreläsningsmanuskript i form av stolpar. Göteborgs naturhistoriska museums arkiv nr 841 .

57. Bo Lindberg och Ingemar Nilsson, Göteborgs universitets historia. Del 1, Göteborg, 1996, 59.

58. Svenska män och kvinnor: Biografisk uppslagsbok. Del 7, Stockholm 1954, 182-183.

59. Svenskt biografiskt lexikon. Band 27, Stockholm 1990-1991, 610-613.

60. Mats Persson, Förnuftskampen: Vitalis Norström och idealismens kris, Stockholm, 1994, 97-103, 111-114.

61. Vitalis Norström, Masskultur. (1910), andra upplagan, Stockholm, 1910, 200, 202, 205-206.

62. Lindberg, Nilsson, 45-48.

63. Jägerskiöld, 1924, 4.

64. Oskar Hörmander, Schartauanismen och sambället: En studie i religiösa och politiska idémotsättningar 1890-1933. Älvsjö, 1980, 45-50, 77, 134, 111-117, 160.

65. Svenska män och kvinnor: Biografisk uppslagsbok Del 8, Stockholm, 1955, 191. Hörmander 20.

66. Göteborgs Museum. Arstryck 1924. Göteborg, 1924, 41.

67. Göteborgs Museum. Arstryck 1925. Göteborg, 1925, 39.

68. Styrelsens sammanträde den 25 september 1925 , $\$ 57$. Göteborgs museum. Protokoll med bilagor 1925 (AI:47). Göteborgs stads arkiv.

69. Hörmander, 20.

70. Ivar D. Wallerius, Den moderna naturåskådningens kris: Utvecklingsläran och verkligheten. Lund, 1917, 52-53.

71. Ibid. 32. 
110 72. Ibid. $110,115-116$.

73. Ibid. 76-77.

74. Hörmander, 129.

75. Den svenska historien. Del 9, Stockholm, 1968, 248-249.

76. Ibid. 280-282.

77. Hettne, Sörlin, Östergård, 276

78. Ibid. 297

79. August Strindberg, En blå bok I (1907) August Strindbergs samlade verk. Nationalupplaga, Stockholm, 1997, 335.

80. Sten Lindroth, Fru Lusta och fru Dygd: Studier och porträtt. (1957), Stockholm 1963, 142-146.

81. Citat efter Hettne, Sörlin, Östergård, 326.

82. Lisbet Koerner, Linnaeus: Nature and Nation, Cambridge, Massachusets \& London, England, 1999, 181

\section{Summary}

National romanticism in a natural history museum of 1923

In Göteborg on the West coast of Sweden a large zoological exhibition belonging to a natural history museum set up in 1923 has been kept well preserved right up to the present day. Only modest changes have been made during the 80 years since the inauguration of the museum. The architectural style of the building is that of national romanticism dating from the years before the First World War. The decision to build the museum was taken before the war. The exhibition is organ- ised according a systemisation of the animal kingdom used by the German zoologist Carl Gegenbaur (18261903). It is however largely constructed in the spirit of Carolus Linnæus (1707-1778), whose scientific ethic was manifested in his magnum opus Systema naturae: "Nomina enim si pereunt, perit \& cognitio rerum." The keeper of the museum Leonard Jägerskiöld (18671945) had already declared in 1903 that a modern zoological museum had to show in its exhibitions results from the most recent research. Why this programme was never realized is a question which might be related to the mental climate in Sweden, and Göteborg in particular, during the period before the war. The leading professors of the College of Göteborg together with the dominant group among the clergy were afraid that modern science might pose a threat to the values of Christian belief and idealistic philosophy. In books and oratory they agitated, sometimes vehemently, against modern science and its alleged materialism. In this intellectual environment an exhibition of modern, Darwinian biology, would necessarily have been regarded as a provocation. In contrast an exhibition which in different ways was reminiscent of Linnaeus was well suited to the demands of this period permeated as it was with nationalism.

Eric Hedqvist är doktorand i museologi vid Institutionen för kultur och medier,

Umea universitet

S-901 87 Umeå 